\title{
EDUKASI KESEHATAN STUNTING DI KABUPATEN BENGKULU UTARA
}

\author{
Health Education Stunting in Bengkulu Utara
}

\section{Wulan Angraini*, Bintang Agustina Pratiwi, M.Amin, Riska Yanuarti, Henni Febriawati, M. Ismail Shaleh}

Program Studi Kesehatan Masyarakat Fakultas Ilmu Kesehatan Universitas Muhammadiyah Bengkulu

*(wulanangraini@umb.ac.id)

\begin{abstract}
ABSTRAK
Pemantauan status gizi Kabupaten Bengkulu Utara bulan Juni 2018 menunjukkan prevalensi stunting $9,03 \%$ dari total 1.289 balita yang diukur status gizi dalam status gizi stunting. Puskesmas Argamakmur merupakan salah satu yang tertinggi jumlah balita dengan status gizi stunting berjumlah 143 orang. Penelitian ini bertujuan untuk mengedukasi kesehatan stunting terhadap pengetahuan dan sikap ibu di Puskesmas Arga Makmur Kabupaten Bengkulu Utara. Penelitian ini menggunakan metode quasy experiment dengan pre dan post test one group pada 29 Juli sampai dengan 19 Agustus 2019 di Puskesmas Arga Makmur Kabupaten Bengkulu Utara. Populasi dalam penelitian ini seluruh ibu yang memiliki balita sedangkan sampel merupakan sebagian ibu yang memiliki anak usia 24-36 bulan dengan teknik accedental sampling sebanyak 19 responden. Analisis data menggunakan uji Compare Means Paired T-Test. Analisis data didapatkan rerata sebelum diberikan edukasi kesehatan terhadap pengetahuan $(4,95)$, sikap $(24,21)$, rata- rata sesudah di berikan edukasi kesehatan terhadap pengetahuan $(7,89)$, sikap $(29,58)$. Rerata pengetahuan dan sikap meningkat tentang stunting setelah edukasi pendidikan kesehatan dalam bentuk flipchat (lembar balik) di Puskesmas Arga Makmur Kabupaten Bengkulu Utara.
\end{abstract}

Kata kunci: Edukasi kesehatan, pengetahuan, sikap, stunting

\section{ABSTRACT}

Monitoring report on Nutrition status in North Bengkulu regency on June 2018 indicated that there were 1,289 children under five (9.03\%) whose nutritional status was measured in the stunting nutritional status. Argamakmur public health care constitutes the highest number of toddlers with stunting nutritional status of 143 people. This researched find out of health education stunting on maternal knowledge and attitudes in Arga Makmur Public Health Care in Bengkulu Utara. The study employed quasy experiment design of pre and post test one group. This study was conducted at the Arga Makmur Public Health Care on 29 July to 19 August 2019. The population was mothers who have toodler and a sample of some mothers with toodler aged 24-36 months at Arga Makmur Public Health Care with an accedental sampling technique were 19 respondents. Analysis data used Compare Means Paired T-Test. Analysis results of the study obtained an average before being given health education to knowledge (4.95), attitude (24.21), on average after being given health education to knowledge (7,89), and attitude (29.58). Increased knowledge and attitudes about stunting after health education interventions in the form of flipchats in Arga Makmur Public Health Care Bengkulu Utara

Keywords: Health education, attitude, knowledge,stunting

\section{PENDAHULUAN}

Stunting adalah hambatan pertumbuhan kurang dari -2SD standar WHO panjang badan menurut usia. ${ }^{1,2}$ Stunting dikatakan tinggi apabila mencapai 30\%-39\% ${ }^{3}$ Pada tahun 2016 secara global terdapat 154.8 juta $(22,9 \%)$ balita mengalami stunting. ${ }^{4}$ Sedangkan di Negara Asia angka kejadian stunting yaitu sebesar $23,9 \%$ atau sebanyak 87 juta anak mengalami stunting ${ }^{5}$

Data terbaru WHO mengungkapakan Asia menduduki peringkat pertama kejadian stunting di dunia. Sebesar 83,6 juta anak balita 
di Asia mengalami stunting, Asia tenggara tertinggi kedua yaitu 25,7 juta anak balita stunting setelah asia selatan. Prediksi pada tahun 2017 akan terdapat 151 juta balita pendek, apabila tidak ada upaya penurunan maka trend ini akan berlanjut sehingga diproyeksikan pada tahun 2025 akan ada 127 juta balita pendek dimana $56 \%$ balita pendek hidup di Asia dan 36\% di Afrika. ${ }^{4}$

Indonesia pada tahun 2014 merupakan salah satu negara dari 117 negara yang memiliki tiga masalah gizi pada balita yaitu overweight, stunting dan wasting. Indonesia pada tahun 2013 terdapat $37,2 \%$ dengan status gizi balita pendek dan sangat pendek, kemudian mengalami penurunan di tahun 2016 menjadi 28,3\% dengan angka kejadian stunting sebanyak 19,8\% dan Severely Stunted (sanga pendek) sebanyak $8,5 \%{ }^{6}$

Di Indonesia, prevalensi anak stunting berbeda beda di setiap daerah. Data nasional pada tahun 2013 menunjukkan $37.2 \%$ balita pendek yang terdiri dari $19.2 \%$ pendek dan $18 \%$ dengan status gizi sangat pendek, prevalensi ini menunjukkan meningkat dari tahun 2010 yaitu $35.65 \%$. Masalah kesehatan masyarakat dianggap berat bila prevalensi stunting sebesar 30\% - 39\% dan serius bila prevalensinya $>40 \%{ }^{7}$

Prevalensi stunting di Indonesia berdasarkan Riskesdas 2013 dalam golongan tinggi karena di angka 37\% dibandingkan dengan prevalensi gizi kurang dan buruk $17,9 \%$, kekurusan $13,3 \%$ dan kegemukan $14 \%{ }^{8}$ Berdasarkan hasil Pemantauan Status Gizi menggunakan Indeks TB/U di Indonesia Tahun 2016 , sebanyak $8,5 \%$ balita mempunyai status gizi sangat pendek dan $19,0 \%$ balita mempunyai status gizi pendek. Hasil PSG Tahun 2017 mengalami peningkatan sebanyak $9,8 \%$ balita mempunyai status gizi sangat pendek dan $19,8 \%$ balita mempunyai status gizi pendek. ${ }^{6}$

Stunting pada balita merupakan masalah gizi paling utama di Indonesia yang menjadi prioritas dihadapi untuk diupayakan menurunkn angka kejadiannya. Stunting memiliki angak prevalensi paling tinggi dibandingkan gizi gemuk, kurang dan kurus berdasarkan data pemantauan tiga tahun terakhir yaitu pada tahun $2016 \quad(27.5 \%$ prevalensi balita pendek), pada tahun 2017 $29.6 \%$ prevalensi balita sangat pendek) dan pada tahun 2018 menjadi $30.8 \%$ prevalensi balita sangat pendek. ${ }^{6}$ Pemantauan status gizi dilakukan untuk dapat melihat perkembangan (trend) dan angka kejadian (prevalensi) stunting sangat dibutuhkan untuk menilai sejauh mana keberhasilan luaran program gizi kesehatan masyarakat dari waktu ke waktu dan penentuan langkah intervensi yang dilakukan dalam upaya peningkatan status gzi masyarakat. ${ }^{9}$

Stunting sebenarnya bukan hanya masalah lebih pendek dari teman sebaya akan tetapi lebih dari itu, anak stunting lebih rawan terhadap penyakit. Anak yang menderita stunting memasuki masa remajanya cenderung menjadi overweight dan rentan terhadap penyakit tidak menular. Hasil penelitian menunjukkan stunting akan berhubungan dengan prestasi belajar rendah, lama pendidikan dan pada saat dia tumbuh dewasa akan berdampak pada penghasilan yang rendah dikarenakan anak stunting memiliki pendidikan yang rendah maka akan berdampak pada pekerjaan dan penghasilannya rendah pula. Pada saat tumbuh dewasa anak dengan status gizi stunting berpeluang tinggi untuk tumbuh menjadi pribadi yang kurang motivasi dalam berpendidikan, kurang mampu dalam segi ekonomi sehingga tidak mampu untuk memenuhi kebutuhan sehari-hari yang berdampak pada kurang diperhatikannya kesehatan dan berakibat lebih rentan terhadap penyakit tidak menular seperti overweight. bahkan lebih dari itu seorang ibu stunting berisiko melahirkan anak stunting pula, sehingga stunting dan segala dampaknya pun akan diwarisi oleh anak. Dengan demikian, stunting merupakan cerminan buruk kualitas sumber daya manusia di masa depan karena stunting tidak serta merta berhenti pada pada saat seseorang menjadi ibu sehingga selanjutnya ibu melahirkan anak yang sudah diwarisi dengan status gizi stunting. Dengan generasi yang memiliki status gizi stunting secara alamiah dan tidak bisa dipunggiri akan secara otomatis menurunkan etos kerja dan kemampuan kognitif dan produktif berdampak menambah beban suatu bangsu di masa yang akan datang. ${ }^{10}$

Provinsi Bengkulu masuk dalam urutan ke 21 tertinggi kasus stunting di Indonesia stelah Banten di posisi ke 20 dengan $(29,6 \%)$ Bengkulu ke 21 dengan (29,4\%) dan Jawa 
Barat dengan ke 22 dengan (29,2\%), kejadian stunting mengalami peningkatan setiap tahunnya, 36\% (2007), 31,6\% (2010), dan 40\% (2013). Kabupaten Bengkulu Utara merupakan urutan pertama tertinggu angka status gizi balita dengan stunting yaitu $35,8 \%{ }^{6}$

Laporan pemantauan status gizi Kabapen Bengkulu Utara Pada bulan juni 2018 terdapat 1.289 balita $(9,03 \%)$ yang diukur status gizi dalam status gizi stunting. Puskesmas Argamakmur merupakan salah satu tertinggi jumlah balita dengan status gizi stunting 14,8 $\%$ dari 143 orang, Puskesmas Batiknaw dengan kasus tertinggi kedua dengan stunting $13,8 \%$ dari 124 orang . ${ }^{11}$

Flipchart atau lembar balik merupakan media perubahan perilaku yang dapat meningkatkan efektivitas dari upaya program pencegahan stunting. ${ }^{12} \quad$ Pendidikan berpengaruh terhadap perilaku baik pengetahuan maupun sikap gizi. ${ }^{13}$

Penelitian Hestuningtyas,

2014 menyimpulkan dengan konseling gizi yang dilakukan terhadap ibu yang memiliki anak stunting usia 1-2 tahun terjadinya peningkatan pengetahuan, sikap dan praktik ibu dalam memberikan makanan anak dan asupan zat gizi anak. ${ }^{14}$ Keikutsertaan ibu dalam kegiatan konseling gizi dapat meningkatkan pengetahuan ibu terhadap asupan gizi, pola makan yang diberikan kepada balita serta meningkatkan kehati-hatian dan kewaspadaan dalam pemilihan bahan makanan, sayur, buah serta lauk nabati dan hewani yang aman dikonsumsi oleh balita gizi kurang. Edukasi gizi juga merupakan salah satu metode yang dapat meningkatkan rerata pengetahuan ibuyang memiliki balita stunting usia 6-24 bulan. ${ }^{15,16}$

Berdasarkan pertimbangan dampak stunting dalam hal-hal berhubungan yang mungkin dapat dicegah, maka peneliti ingin mengedukasi kesehatan ibu yang memiliki balita stunting di Puskesmas Arga Makmur Kabupaten Bengkulu Utara. di mengetahui pengaruh pendidikan kesehatan terhadap pengetahuan dan sikap ibu tentang kejadian stunting di Puskesmas Argamakmur Kabupaten Bengkulu Utara.

\section{METODE PENELITIAN}

Metode penelitian menggunakan quasy eksperiment dengan desain pre dan post one group. Penelitian dilaksanakan tanggal 29 Juli sampai dengan 19 Agustu 2019 di wilayah kerja Puskesmas Arga Makmur Kabupaten Bengkulu Utara. Populasi penelitian merupakan seluruh ibu yang memiliki balita sedangkan sampel ibu yang memiliki balita usia 24-36 bulan (2-3 tahun) yang dimabil dengan teknik Accidental Sampling yaitu 19 orang ibu. Pada proses pengumpulan data menggunakan wawancara dibantu dengan kuesioner yang sudah disiapkan berisikan tentang pengertian, penyebab, dampak, dan pencegahan stunting yang sebelumnya sudah diuji validitas dan reabilitas sebelum dilakukan penelitian. Metode pendidikan kesehatan yang diberikan kepada ibu dengan menggunakan flipchart (lembar balik) yang berisi materi tentang stunting. Penganalisian data menggunakan uji Compare Means Paired ttest.

\section{HASIL}

Dari hasil penelitian sampai dengan analisis data didapat distribusi frekuensi karakteristik ibu, pengetahuan dan sikap ibu yang memiliki balita 24-36 bulan sebelum dan setelah diberikan edukasi kesehatan stunting di Puskesmas Arga Makmur Kabupaten Bengkulu Utara sebagai berikut:

Tabel 1. Karakteristik Ibu di Puskesmas Arga Makmur Kabupaten Bengkulu Utara

\begin{tabular}{|c|c|c|}
\hline Variabel & Frekuensi & Persentasi \\
\hline \multicolumn{3}{|l|}{ Umur } \\
\hline 20-29 tahun & 9 orang & $47.4 \%$ \\
\hline $30-45$ tahu & 10 orang & $52,6 \%$ \\
\hline \multicolumn{3}{|l|}{ Pendidikan } \\
\hline $\mathrm{SD}$ & 2 orang & $10.5 \%$ \\
\hline SMP & 2 orang & $10.5 \%$ \\
\hline SMA & 8 orang & $42.1 \%$ \\
\hline Sarjana & 7 orang & $36.8 \%$ \\
\hline \multicolumn{3}{|l|}{ Pekerjaan } \\
\hline IRT & 14 orang & $73.7 \%$ \\
\hline Swasta & 2 orang & $10.5 \%$ \\
\hline PNS & 2 orang & $10.5 \%$ \\
\hline Honorer & 1 orang & $5.3 \%$ \\
\hline Total & 19 orang & $100 \%$ \\
\hline
\end{tabular}


sebagian besar ibu balita berusia 30-45 tahun (52.6\%), pendidikan ibu sebagian besar berpendidikan SMA (42.1\%) dan pekerjaan ibu sebagian sebagai Ibu Rumat Tangga (IRT) 14 orang $(73.7 \%)$.

Tabel 2. Distribusi Rata-Rata Kategori Pengetahuan dan Sikap Ibu Sebelum dan Sesudah Diberikan Edukasi Kesehatan Stunting Puskesmas Arga Makmur Kabupaten Bengkulu Utara

\begin{tabular}{lllllll}
\hline Variabel & Mean & Std. Deviasi & Std. Erorr & Min-Max & P Value & 95\%CI \\
\hline Pengetahuan & & & & & & \\
Pretest & 4.95 & 2.656 & 0,609 & $1-9$ & 0,000 & $3.69-6.23$ \\
Posttest & 7.89 & 0.737 & 0,169 & $6-9$ & & $7.54-8.25$ \\
\hline Sikap & & & & & & \\
Pretest & 24.21 & 6.554 & 1,504 & $10-34$ & 0,002 & $21.05-27.37$ \\
Posttest & 29.58 & 2.479 & 0,569 & $25-34$ & & $28.38-30.77$ \\
\hline
\end{tabular}

Sumber : Data Primer, 2019

objek tertentu. Terbentuknya tindakan

Rerata pengetahuan ibu di Puskesmas Arga Makmur Kabupaten Bengkulu Utara sebelum diberikan edukasi kesehatan tentang stunting yaitu 4.95 yang memiliki standar deviasi 2.656 sedangkan rerata pengetahuan ibu setelah diberikan edukasi kesehatan tentang stunting terjadi peningkatan yaitu menjadi 7.89 yang memiliki standar deviasi 0.737 dengan $p$ value 0,000 . Dengan demikian artinya ada perubahan peningkatan pengetahuan ibu sebelum dan setelah diberikannya edukasi kesehatan tentang stunting di Puskesmas Arga Makmur Kabupaten Bengkulu Utara.

Rerata sikap ibu yang memiliki balita 2436 tahun di Puskesmas Arga Makmur Kabupaten Bengkulu Utara sebelum diberikan edukasi kesehatan tentang stunting yaitu 24.21 yang memiliki standar deviasi 6.554 sedangkan rerata sikap ibu setelah diberikan edukasi kesehatan tentang stunting terjadi peningkatan menjadi 29.58 yang memiliki standar deviasi 2.479 dengan $p$ value 0,002 Dengan hasil tersebut artinya ada peningkatan sikap ibu sebelum dan setelah diberikan edukasi kesehatan tentang stunting di Puskesmas Arga Makmur Kabupaten Bengkulu Utara

\section{PEMBAHASAN}

\section{Pengetahuan Ibu Sebelum dan Setelah diberikan Edukasi Kesehatan tentang Stunting}

Konsep pengetahuan adalah proses hasil 'tahu' seseorang terjadi setelah dilakukkannya pengindraan atau intervensi terhadap suatu seseorang dipengaruhi secara besar dari pengetahuan yang dimilikinya. ${ }^{17}$ Penelitian ini menyimpulkan adanya peningkatan pengetahuan ibu sebelum dan setelah diberikannya edukasi kesehatan tentang stunting artinya bahwa edukasi kesehatan mempunyai pengaruh positif terhadap pengetahuan ibu. Berdasarkan hasil penelitian tersebut dapat dikatakan bahwa edukasi kesehatan dengan menggunkan media cetak seperti flipchat (lembar balik) dapat meningkatkan pengetahuan ibu dalam mengenali stunting, penyebab stunting, gejala stunting dan dampak dari stunting. Pengetahuan yang dimiliki oleh ibu tentang stunting akan menjadi cerminan kesehatan dan kesejahteraan anak dan penentu masa depan anak di masa yang akan datang. ibu yang sering mendapatkan edukasi kesehatan tentang stunting akan memiliki pengetahuan yang lebih informative dan lebih bervariasi dibandingkan dengan ibu yang kurang berpartisi pasi dlaam edukasi kesehatan.

Dari hasil penelitian bahwa peneliti menemukan peningkatan pengetahuan sebelum diberikan pendidikan kesehatan dari sebelumnya hanya 9 ibu yang mengetahui apa itu stunting dan setelah di berikan pendidikan kesehatan semua ibu menjadi tahu apa yang dimaksud dengan stunting, dari kuesioner variabel pengetahuan pertanyaan nomor 7 peneliti menyimpulkan bahwa sebagian besar ibu setelah di berikan pendidikan kesehatan mengetahui bahwa stunting adalah masalah kekurangan gizi dari sebelum perlakuan setengah dari responden tidak tahu bahwa stunting disebabkan kekurangan gizi pada saat kehamilan. 
Penelitian menunjukkan bahwa pendidikan kesehatan tentang pencegahan stunting akan berdampak pada pengetahuan ibu, ibu yang memiliki kurang informasi maka akan memiliki pengetahuan kurang juga terhadap pencegahan stunting. ${ }^{18}$ Perubahan peningkatan pengetahuan ibu dan kader posyandu setelah diberikan promosi kesehatan dengan media integrating card. ${ }^{19}$

Tingkat pendidikan seseorang akan berpengaruh terhadap pengetahuan yang dimilikinya. Pendidikan ibu menjadi salah satu faktor yang terjadinya stunting pada anak. ${ }^{20}$ Pendidikan kesehatan dapat dilakukan melalui beberapa metode salah satunya adalah metode konseling, dimana dengan melakukan konseling dapat meningkatkan pengetahuan dan sikap ibu. ${ }^{21}$

Kejadian stunting banyak faktor yang mempengaruhinya salah satunya adalah kurangnya pengetahuan yang dimiliki ibu tentang asupan gizi dan status gizi. ${ }^{22}$ anak yang dilahirkan oleh ibu dengan pendidikan yang rendah lebih beresiko terkena stunting, artinya meningkatan pengetahuan ibu akan membuat pertumbuhan anak menjadi lebih baik. ${ }^{23}$ Pendidikan ibu yang rendah membuat ibu tidak memanfaatkan pelayanan kesehatan akibat kurangnya pengetahuan sehingga dapat menyebabkan terjadinya stunting. ${ }^{24}$ Pengetahuan erat kaitannya dengan kejadian stunting pada anak yang memasuki sekolah dasar. ${ }^{25}$

Berdasarkan hasil penelitian menunjukkan edukasi kesehatan tentang stunting menggunakan flipchat (lembar balik) berpengaruh penting karena mendapatkan informasi yang menarik dan pengetahuan tentang stunting.

\section{Sikap Ibu Sebelum dan Setelah diberikan Edukasi Kesehatan Tentang Stunting}

Reaksi atau respon sesorang yang masih tersembunyi atau tertutup terhadap suatu stimulus atau objek merupakan bentuk dari sikap seseorang.. ${ }^{26}$ Sikap merupakan penentu kecenderungan menerima atau menolak suatu tindakan yang akan dilakukan dan sebelum melakukan aktivitas. Berdasarkan hasil penelitian dapat disimpulkan edukasi kesehatan tentang stunting menggunakan media cetak seperti flipchart (lembar balik) berpengaruh terhadap sikap ibu, semua responden mendapatkan nilai sikap yang positif.

Dari hasil temuan di lapangan bahwa sikap ibu berubah setelah ada peningkatan pengetahuan dari sebelum pendidikan kesehatan dan banyak ibu yang tidak mengetahui apa itu stunting dan jawaban pertanyaan sikap sebagian ibu bersikap baik setelah di berikan pendidikan kesehatan, pertanyaan nomor 3-7 menjelaskan stunting dapat dicegah dan ibu sebelum diberikan pendidikan kesehatan sebagian ibu bersikap negatif dikarenakan tidak tahu apa yang dimaksud dengan stunting, tetapi setelah diberikan pendidikan kesehatan semua ibu bersikap positif dikarenakan peningkatan pengetahuan mereka.

Pendidikan kesehatan memiliki pengaruh terhadap sikap ibu dalam pencegahan stunting. ${ }^{18}$ Penelitian menyebutkan adanya hubungan antara sikap ibu dengan kejadian stunting pada anak baru masuk sekolah dasar. ${ }^{25}$

Hasil penelitian menunjukan bahwa antara teori dan fakta memiliki kesamaan hal ini dibuktikan ibu yang memiliki anak 24-36 tahun setelah diberikan eduaksi kesehatan tentang stunting didapatkan semua ibu memiliki sikap yang sangat positif.

Sikap ibu yang kurang mendukung akan mempengaruhi perilaku ibu dalam mengkonsumsi makanan selama kehamilan. Asupan gizi pada saat masa kehamilan merupakan masa yang termasuk dalam 1000 HPK yang sangat perlu diperhatikan muali dari konsumisi asupan gizi yang seimbang hingga konsumsi tablet fe karena dengan mengkonsumsi tablet fe secara rutin dapat mencegah terjadinya berat badan lahir rendah.. Berat badan lahir rendah merupakan cikal bakal akan terjadinya stunting pada anak. Dengan kata lain ibu yang melahirkan anak dengan berat badan lahir rendah akan berisiko terjadinya stunting ${ }^{27}$

\section{KESIMPULAN DAN SARAN}

Rerata pengetahuan dan sikap meningkat tentang stunting setelah diberikan intervensi edukasi kesehatan dalam bentuk flipchat (lembar balik) di Puskesmas Arga Makmur Kabupaten Bengkulu Utara. Tindak lanjut dari penelitian ini adalah adanya evaluasi dari pihak Puskesmas terkait dengan 
metode atau penyampaian informasi bagi para ibu, calon ibu yang berkunjung ke Puskesmas Arga Makmur Kabupaten Bengkulu Utara

\section{UCAPAN TERIMA KASIH}

Ucapan terima kasih penulis sampaikan Ucapan terima kasih penulis sampaikan kepada Kemenristek Dikti dan Universitas Muhammadiyah Bengkulu serta Puskesmas Kota Arga Makmur Kabupaten Bengkulu Utara yang telah banyak membantu pada saat penelitian ini.

\section{DAFTAR PUSTAKA}

1. Nasrul, Hafid F, Razak Thaha A, Suriah. Faktor Risiko Stunting Usia 6-23 Bulan dI Kecamatan Bontoramba Kabupaten Jeneponto. Media Kesehat Masy Indones. 2015;11(3):139-46.

2. Kadar Ramadhan. Status Gizi menurut Tinggi Badan per Umur pada Balita. Poltekita J Ilmu Kesehat [Internet]. 2019 Apr 27;13(2):96-101. Available from: http://jurnal.poltekkespalu.ac.id/index.php/J $\mathrm{IK} /$ article/view/38

3. WHO. WHA Global Nutrition Targets 2025: Stunting Policy Brief. WHO. 2014;9.

4. WHO. Reducing stunting in children. Equity considerations for achieving the Global Nutrition Targets 2025. 2018. 40 p.

5. Unicef/ WHO/The World Bank. Levels and Trends in Child malnutrition - Unicef WHO The World Bank Joint Child Malnutrition Estimates, key findings pf the 2019 edition. Unicef. 2019;4.

6. Kementerian Kesehatan RI. Buku saku pemantauan status gizi. Buku saku pemantauan status gizi tahun 2017. 2018;711.

7. WHO. Interpretation guide. Nutr Landsc Inf Syst Ctry Profile Indic. 2010;1-51.

8. Kemenkes. Penyajian Pokok-Pokok Hasil Riset Kesehatan Dasar 2013. 2013;

9. Nasrul, Maudu R, Hafid F. Trend and Prevalence of Stunting in Children Under Two Years From 2007- 2016 In Central Sulawesi. Prev J Kesehat Masy. 2017;8(2):73-8.

10. Maschinen B, Investition A, Beschaffungen G, Ersatzbeschaffungen B, Mittelherkunft S. Ringkasan Kajian Gizi; Ibu dan Anak. 2012.

11. Dinkes Bengkulu Utara DBU. Laporan Data Pemantauan Status Gizi Kabupaten Bengkulu Utara. 2018.
12. Nasrul, Zainul, Hafid F, Taqwin. Manfaat Media Flipchart dan Spanduk dalam Perilaku Kesehatan 1000 HPK di Sulawesi Tengah. Media Kesehat Masy Indones. 2018;14(1):52-60.

13. Hafid F, Nasrul N. Pengaruh Pendidikan Gizi 1000 HPK Terhadap Perilaku Gizi Remaja di Sulawesi Tengah. In: Kongres Nasional Ikatan Ahli Kesehatan Masyarakat Indonesia XIII Makassar. ISBN: 978-60260432-0-7; 2016. p. 497.

14. Hestuningtyas, Tiara Rosania; Noer ER. Pengaruh Konseling Gizi Terhadap Pengetahuan, Sikap, Praktik Ibu Dalam Pemberian Makan Anak, Dan Asupan Zat Gizi Anak Stunting Usia 1-2 Tahun Di Kecamatan Semarang Timur. Vol. 3. 2014. $17-25 \mathrm{p}$.

15. Kusumaningrum R, Pudjirahaju A. Konseling Gizi Terhadap Pengetahuan Gizi Dan Sikap Ibu, Pola Makan Serta Tingkat Konsumsi Energi Dan Protein Balita Gizi Kurang. J Inf Kesehat Indones. 2018;4(1):53.

16. Dewi, Maryati; Aminah M. Pengaruh Edukasi Gizi terhadap Feeding Practice Ibu Balita Stunting Usia 6-24 Bulan. Indones J Hum Nutr. 2017;1(1):14-22.

17. Notoatmodjo S. Promosi Kesehatan dan Perilaku Kesehatan. Yogyakarta: Rineka Cipta; 2014.

18. Suryagustina. Pengaruh Pendidikan Kesehatan Tentang Pencegahan StuntingTerhadap Pengetahuan Dan Sikap Ibu di Kelurahan Pahandut Palangka Raya. Din Kesehat. 2018;9(2).

19. Astuti S dan, dkk. Promotive Efforts To Improve the Knowledge of Mother of Toddlers About. J Pengabdi Kpd Masy. 2018;2(6).

20. Suryani D, Yosephin B, Miratulhaya, Dailin, Yandrizal, Bintang Agustina $\mathrm{P}$, et al. Policy and determinant analysis in effort to control stunting case in bengkulu province. Indian J Public Heal Res Dev. 2018;

21. Pratiwi BA. Pengaruh Konseling terhadap Pengetahuan dan Sikap Ibu Tentang Asi Eksklusif di Wilayah Kerja Puskesmas Lingkar Barat Kota Bengkulu. Avicenna. 2019;14(01).

22. Seedhom A.E, Mohamed E.S MEM. Determinants of stunting among preschool children, Minia, Egypt. Int Public Heal Forum. 2014;1(2):6-9.

23. Abuya BA, Onsomu EO, Kimani JK, Moore D. Influence of maternal education on child immunization and stunting in 
Kenya. Matern Child Health J. 2011;15(8):1389-99.

24. Senbanjo IO, Oshikoya KA, Odusanya OO, Njokanma OF. Prevalence of and risk factors for stunting among school children and adolescents in Abeokuta, Southwest Nigeria. J Heal Popul Nutr. 2011;29(4):364-70.

25. Olsa ED, Sulastri D, Anas E. Hubungan Sikap dan Pengetahuan Ibu Terhadap Kejadian Stunting pada Anak Baru Masuk Sekolah Dasar di Kecamanatan Nanggalo. J
Kesehat Andalas. 2018;6(3):523.

26. Notoatmodjo S. Promosi Kesehatan dan Ilmu Perilaku. Jakarta: Rineka Cipta; 2017.

27. Angraini, Wulan., Pratiwi, Bintang Agustina., Amin, Moh., Yanuarti, Riska., Hajuarti T. Berat Badan Lahir sebagai Faktor Risiko Kejadian Stunting di Kabupaten Bengkulu Utara. Avicenna J Ilm. 2019;14(2). 